\title{
Lokuskipti vegna ósæðarlokuprengsla á Íslandi 2002-2006: Langtímafylgikvillar og lifun
}

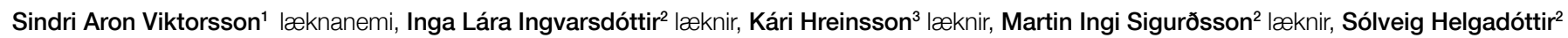
læknir, Pórarinn Arnórsson ${ }^{2}$ æknir, Ragnar Danielsen ${ }^{1,4}$ læknir, Tómas Guðbjartsson ${ }^{1,2}$ læknir

\section{ÁGRIP}

Inngangur: Markmiðið̃ var að kanna langtímaárangur lokuskipta vegna ósæđarlokuprengsla á Íslandi.

Efniviður og aðferðir: Rannsóknin tók til 156 sjúklinga (meðalaldur 71,7 ár, 64,7\% karlar) sem gengust undir ósæðarlokuskipti vegna ósæðarlokuprengsla á Landspítala 2002-2006. Gerviloku var komið fyrir hjá 29 sjúklingum en lífrænni loku hjá 127. Skráðir voru langtímafylgikvillar og innlagnir tengdar aðgerðinni fram til 1. apríl 2010. Stuðst var við sjúkraskrár og stofunótur sérfræðinga. Einnig var farið yfir hjartaómanir við eftirfylgd, reiknuð út heildarlifun og hún borin saman við meðallifun Íslendinga af sama aldri og kyni.

Niðurstöður: Meðal EuroSCORE (st) fyrir aðgerð var 6,9\%, hámarksprýstingsfall yfir lokuna 74,1 mmHg og útfallsbrot vinstri slegils (EF) $57,2 \%$. Hálfu ári eftir aðgerð mældist hámarksprýstingsfall yfir nýju lokuna 19,8 mmHg (bil 2,5-38,0). Ómskoðun við eftirlit hjá hjartalækni vantaði hjá tæpum fjórðungi sjúklinga. Á eftirlitstímanum var rúmur fjórðungur sjúklinga lagður inn vegna vandamála sem tengdust lokunni. Tíoni endurinnlagna var 6,0/100 sjúklingaár. Algengustu ástæður endurinnlagna voru hjartabilun (1,7/100 sjúklingaár), blóðsegarek (1,6/100 sjúklingaár), blæðing (1,6/100 sjúklingaár), hjartapelsbólga ( $0,7 / 100$ sjúklingaár) og hjartadrep (0,4/100 sjúklingaár). Eins og fimm ára lifun eftir aðgerð var $89,7 \%$ og $78,2 \%$ og reyndist sambærileg við lifun Íslendinga af sama aldri og kyni.

Ályktun: Tíoni langtímafylgikvilla eftir ósæðarlokuskipti hér á landi er svipuð og erlendis. Langtímalifun er góð og sambærileg við lifun einstaklinga af sama kyni og aldri sem ekki gengust undir ósæðarlokuskipti.

'Læknadeild HÍ, " hjartaog lungnaskurðdeild, ${ }^{3}$ svæfinga- og gjörgæsludeild,

${ }^{4}$ hjartadeild

Landspítala.

Fyrirspurnir: Tómas Guðbjartsson tomasgud@landspitali.is

Barst: 23. apríl 2011, sampykkt til birtingar 7. júlí 2011

Höfundar tiltaka engin hagsmunatengsl.

\section{Inngangur}

Frá árinu 1987 hafa verið framkvæmdar hátt í 900 ósæðarlokuskiptaaðgerðir hér á landi, oftast vegna ósæðarlokuprengsla. ${ }^{1}$ Pessum aðgerðum hefur stöðugt fjölgað og í ljósi aukins fjölda eldra fólks á Íslandi má gera ráð fyrir að aðgerðirnar verði enn fleiri á komandi árum. ${ }^{2}$

Sjúklingar með ósæðarlokuprengsli sem gangast undir ósæðarlokuskipti hafa flestir einkenni vegna sjúkdómsins, einkum mæði eða hjartabilun. Án aðgerðar er dánarhlutfall pessara sjúklinga allt að $56 \%$ innan tveggja ára. ${ }^{3}$ Erlendar rannsóknir benda til að prátt fyrir háan aldur stórs hluta sjúklinganna lifi ríflega $90 \%$ peirra af aðgerðina og fimm árum eftir aðgerð eru 75\% peirra á lífi. ${ }^{4}$ Ávinningur af ósæðarlokuskiptaaðgerð er pví ótvíræður bæði hvað bætta lifun og lífsgæði varðar. ${ }^{4}$

Fylgikvillar eftir ósæðarlokuskipti eru tíðir, ekki síst snemmkomnir fylgikvillar á fyrstu dögum og vikum eftir aðgerðina. ${ }^{4}$ Langtímafylgikvillar sem koma mánuðum eða árum eftir aðgerð eru hins vegar mun sjaldgæfari. ${ }^{5}$ Peir eru misalvarlegir, allt frá vægum blæðingum sem oftast tengjast blóðpynningarmeðferð til lífshættulegrar hjartapelsbólgu eða segamyndunar í lokunni. ${ }^{6,7}$

Hér á landi hefur vantað upplýsingar um árangur ósæðarlokuaðgerða. Í síðasta Læknablaði birtust niðurstöður sömu höfunda um snemmkominn árangur pessara aðgerða með áherslu á fylgikvilla og dánartíðni á fyrsta mánuði eftir aðgerð. ${ }^{8}$ Í peirri rannsókn var byggt á sama sjúklingapýði en hér er sjónum beint að langtímafylgikvillum og lifun.

\section{Efniviður og aðferðir}

Rannsóknin var afturskyggn og náði til 156 sjúklinga sem gengust undir ósæðarlokuskipti vegna ósæðarlokuprengsla á Landspítala frá 1. janúar 2002 til 31. desember 2006. Efniviði rannsóknarinnar hefur verið lýst annars staðar. ${ }^{8}$ Sjúklingum sem gengust undir ósæðarlokuskipti vegna annarra ábendinga var sleppt.

Samtals voru skráđar 113 breytur úr sjúkraskrám og eru pær helstu taldar upp í heimild 8. Flokkun NYHA (New York Heart Association) var notuð til mats á alvarleika hjartabilunar og reiknuð var áhætta á dauða innan 30 daga frá aðgerð með EuroSCORE (bæði standard og lógistískt áhættulíkaninu). Að auki voru skráðar 13 breytur úr hjartaómskoðunum, fyrir aðgerð, viku eftir aðgerð og um pað bil sex mánuðum síðar. Meðal annars var skráð hámarksprýstingsfall yfir ósæðarlokuna, hvort leki var til staðar, útfallsbrot vinstri slegils ásamt pykkt og stærð hans í panbili. Leitað var eftir ómskoðunarsvörum í gagnagrunni Landspítala, á Sjúkrahúsinu á Akureyri og á einkastofum hjartasérfræðinga.

Ómskoðunarsvör fundust fyrir 156 sjúklinga (100\%) fyrir aðgerð og fyrir 95 af 145 sjúklingum (65,5\%) fyrir útskrift. Hins vegar fundust einungis ómskoðunarsvör fyrir 90 af peim 140 sjúklingum (64,3\%) sem voru á lífi 12 mánuðum eftir aðgerð. Hjá 34 af peim 50 sjúklingum sem ekki fundust ómskoðunarsvör fyrir, var staðfest að ekki hefði verið gerð ómskoðun á hjarta eftir útskrift af hjartaskurðdeild. Flestir sjúklinganna höfðu pó verið undir klínísku eftirliti á rannsóknartímabilinu. 
Tafla I. Niðurstöður hjartaómana fyrir aðgerð og um pað bil hálfu ári síðar hjá sjúklingum sem gengust undir lokuskipti vegna ósæðarlokuprengsla á Íslandi 2002-2006. Alls fundust ómanir fyrir 63 einstaklinga á tímabilinu, par af fundust upplýsingar um útfallsbrot i 52 tilfellum og upplýsingar um pvermál vinstri slegils i panbili, hámarksprýstingsfall og sleglaskiptapykkt hjá 49 sjúklingum. Gefin eru upp meðaltöl og stađalfrávik eđa fjöldi sjúklinga með \% í sviga.

\begin{tabular}{lccc}
\hline \multicolumn{1}{c}{ Niðurstöður } & Fyrir aðgerð & $\begin{array}{c}\text { Viku eftir } \\
\text { aðgerð }\end{array}$ & $\begin{array}{c}6 \text { mánuðum eftir } \\
\text { aðgerð }\end{array}$ \\
\hline Útfallsbrot (\%) & $57,2 \pm 7,7$ & $50,4 \pm 9,1$ & $54,8 \pm 8,6$ \\
\hline $\begin{array}{l}\text { Pvermál vinstri slegils } \\
\text { í panbili (cm) }\end{array}$ & $5,3 \pm 0,9$ & $5,2 \pm 0,8$ & $5,2 \pm 0,8$ \\
\hline $\begin{array}{l}\text { Hámarksprýstingsfall yfir } \\
\text { lokuna (mmHg) }\end{array}$ & $74,1 \pm 25,3$ & $28,1 \pm 10,1$ & $19,8 \pm 7,3$ \\
\hline Sleglaskiptapykkt (cm) & $1,4 \pm 0,3$ & $1,5 \pm 0,3$ & $1,3 \pm 0,3$ \\
\hline Lokuleki (fjöldi, \%) & Á ekki við & $7 / 152(4,6)^{\star}$ & $9 / 140(6,4)^{\star}$ \\
\hline Hliðarlokuleki (fjöldi, \%) & Á ekki við & 0 & $3 / 140(2,1)$ \\
\hline
\end{tabular}

*Vægur leki í öllum tilvikum

Fylgikvillar eftir aðgerð voru ítarlega skráðir. Snemmkomnir fylgikvillar töldust peir sem komu upp innan fjögurra vikna frá aðgerð en annars töldust peir langtímafylgikvillar. Sjúklingum var fylgt eftir með rafrænu sjúkraskrárkerfi sjúkrahúsanna fram til 1. apríl 2010. Skráđar voru allar endurinnlagnir á sjúkrahús sem tengdust lokuaðgerðinni, lokunni sjálfri, blóðpynningu eða öðrum skyldum hjartavandamálum. Auk pess voru í samráði við hjartalækna viðkomandi sjúklinga, kannaðar endurkomunótur á einkastofum með tilliti til endurinnlagna á sjúkrahús. Leitað var sérstaklega að fylgikvillum sem tengdust ósæðarlokunni eða hjartanu, svo sem bilun í lokunni, leki í eða til hliðar við lokuna, segamyndun, blóðsegarek, blæðingar sem tengdust blóðpynningu og hjartapelsbólgu. Tíðni fylgikvilla var skráð samkvæmt alpjóðlegum stöðlum sem notaðir hafa verið í sambærilegum erlendum rannsóknum. ${ }^{9}$ Tíðni langtímafylgikvilla er gefin upp sem fjöldi tilfella á 100 sjúklingaár, en samtals voru sjúklingaár 749 og meðaleftirlitstími 4,8 ár (bil 0-8,3).

Upplýsingaskráning og lýsandi tölfræði var gerð með forritinu Excel. Við samanburð hópa var stuðst við t-próf fyrir samfelldar breytur og Fisher Exact eða Kí-kvaðrat próf fyrir hlutfallsbreytur. Heildarlifun hópsins var metin með aðferð Kaplan-Meier. Afstæð lifun (relative survival) var metin með pví að reikna út væntanlega lifun hvers einstaklings sem gekkst undir aðgerð miðað við kyn, aldur og aðgerðarár. Til viðmiðunar var notuð tafla yfir væntanlega lifun Íslendinga og var hún sótt á vef Hagstofunnar (www.hagstofa.is). Tölfræðiútreikningar voru gerðir í R forritinu, útgáfu 2.11.0 (The $\mathrm{R}$ foundation, Austria) og marktæki miðast við tvíhliða p-gildi $<0,05$.

Áður en rannsóknin hófst fengust öll tilskilin leyfi frá Vísindasiðanefnd, Persónuvernd og framkvæmdastjóra lækninga á Landspítala.

\section{Niðurstöठur}

Af 156 sjúklingum var 101 karl (64,7\%) og var meðalaldur hópsins 71,7 ár (bil 41-88). Lífrænni loku var komið fyrir í 127 sjúklingum $(81,4 \%)$, par af fengu 102 peirra grindarlausa lífræna loku $(65,4 \%)$ og 25 lífræna loku með grind (16,0\%). Gerviloku var komið fyrir í 29 sjúklingum (18,6\%) og voru peir að meðaltali 16 árum yngri en peir sem fengu lífræna loku $(\mathrm{p}<0,0001)$. Fjölda aðgerða

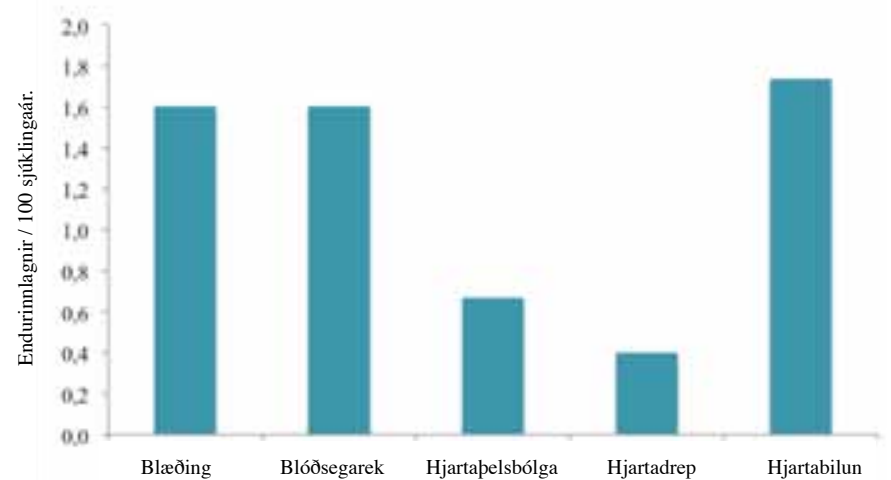

Mynd 1. Tíðni langtímafylgikvilla hjá 156 sjúklingum sem gengust undir lokuskipti vegna ósæðarlokuprengsla á Íslandi 2002-2006. Tíðnitölur eru gefnar upp sem fjöldi endurinnlagna á hver 100 sjúklingaár. Fjórir sjúklingar voru skráðir með fleiri en einn fylgikvilla.

og tegund af loku sem grædd var í sjúklingana er að finna í heimild númer 8 . Hjá 86 sjúklingum $(55,1 \%)$ var einnig gerð kransæðahjáveita, míturlokuaðgerð hjá níu sjúklingum (5,8\%) og MAZE-aðgerð vegna gáttatifs hjá átta sjúklingum (5,1\%). Aðrar aðgerðir samhliða ósæðarlokuskiptum voru fátíðari.

Rúmlega tveir priðju sjúklinga höfðu sögu um reykingar, 69,2\% sögu um háprýsting og 43,6\% sögu um hækkaðar blóðfitur. Sjúklingar á NYHA-stigum III-IV voru $89(57,1 \%)$ og $15(9,6 \%)$ í flokki I. EuroSCORE (st) var að meðaltali 6,9 $\pm 3,0$ (bil 2-18). Stærð ígræddrar loku var að meðaltali 25,6 mm (bil 21-29).

Snemmkomnum fylgikvillum hefur áður verið lýst í heimild 8. Tíu sjúklingar létust innan 30 daga frá aðgerð og skurðdauði var pví 6,4\%. Aðeins einn sjúklingur lést á sjúkrahúsi eftir meira en 30 daga, nánar tiltekið 33 dögum frá aðgerð. Heildarlegutími var 13 dagar (miðgildi, bil 0-207) og er pá talinn með einn dagur á gjörgæslu (miðgildi, bil 0-80).

Í töflu I sjást niðurstöður ómskoðana fyrir aðgerð, viku eftir aðgerð og um hálfu ári eftir aðgerð. Meðalútfallsbrot og stærð vinstri slegils í lok panbils var sambærileg fyrir og eftir aðgerð. Hámarksprýstingsfall yfir lokuna lækkaði hins vegar, eða í 19,8 $\mathrm{mmHg} \pm 7,3$ úr 74,1 mmHg $\pm 25,3$ fyrir aðgerð $(\mathrm{p}=<0,0001)$. Marktækur leki í nýju lokunni (greinanlegur á ómskoðun sem $\geq 1$ á kvarða frá 1 til 3) greindist hjá níu sjúklingum, og voru peir allir með lífræna loku. Hliðarlokuleki greindist með vissu hjá premur sjúklingum en enginn peirra purfti að fara aftur í aðgerð.

Á mynd 1 sést tíðni langtímafylgikvilla miðað við hver 100 sjúklingaár. Í pessum tölum eru ekki teknir með sjúklingar sem létust innan mánaðar frá aðgerð. Alls voru lokutengdar endurinnlagnir 45 talsins en fjórir sjúklingar lögðust inn tvisvar eða fengu fleiri en einn fylgikvilla. Heildartíðni langtímafylgikvilla mældist pví 6,01 á hver 100 sjúklingaár. Flestar endurinnlagnir voru vegna hjartabilunar ( $\mathrm{n}=13,1,7 / 100$ sjúklingaár). Endurinnlagnir vegna blæðinga voru 12 (1,6/100 sjúklingaár); par af 11 (1,5/100 sjúklingaár) vegna blæðingar í meltingarvegi og ein (0,1/100 sjúklingaár) vegna blæðingar í miðtaugakerfi. Tólf sjúklingar fengu blóðsegarek (1,6/100 sjúklingaár), par af greindust fimm sjúklingar með heilablóðfall (0,7/100 sjúklingaár), aðrir fimm (0,7/100 sjúklingaár) með tímabundna blóðpurrð í heila og tveir (0,1/100 sjúklingaár) með blóðsegarek í útlim. Hjartapelsbólga var orsök endurinnlagnar hjá fimm sjúklingum (0,7/100 sjúklingaár) en hjartadrep 


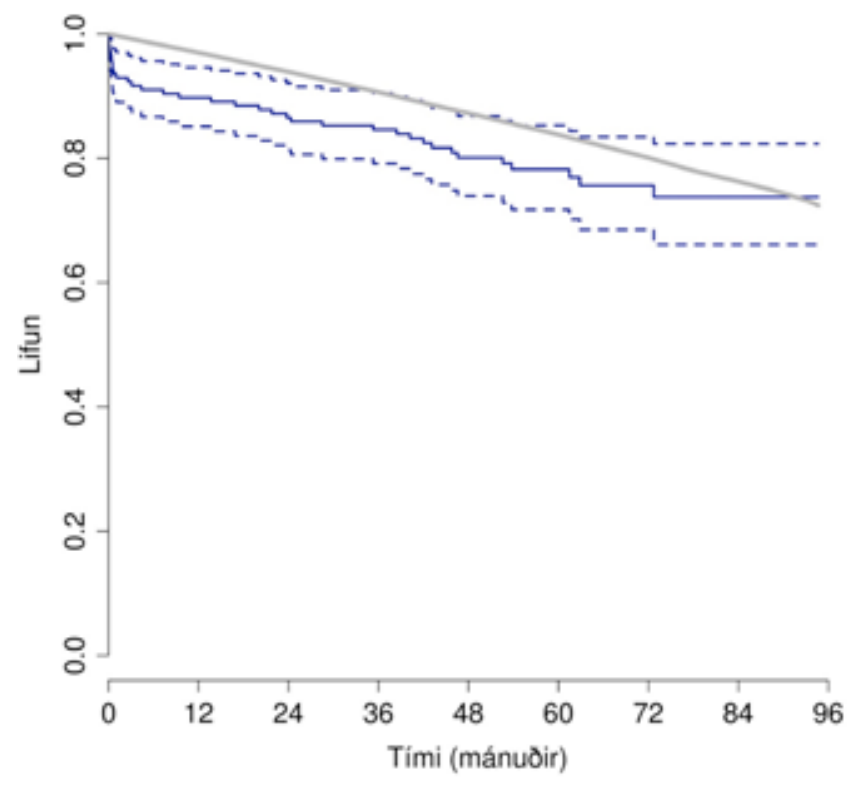

Mynd 2. Heildarlifun sjúklinga sem gengust undir lokuskipti vegna ósæðarlokuprengsla á Islandi á tímabilinu 2002-2006. Gráa línan sýnir áxtlaða lifun Islendinga af sama kyni og aldri yfir sama tímabil. Eftir fjögur ár sker línan við 95\% vikmörk heildarlifunar sjúklinga (blá brotalína) og er munurinn milli hópa par með ekki lengur marktækur (log rank próf).

hjá premur (0,4/100 sjúklingaár). Enginn sjúklinganna var lagður inn vegna sega á lokunni eða purfti á nýrri aðgerð að halda.

Fimm sjúklingar fengu hjartapelsbólgu á tímabilinu samkvæmt greiningarskilmerkjum Dukes. Greiningin var í öllum tilvikum nema einu fengin með vélindaómun og blóðræktunum. Einn sjúklingur lést á gjörgæslu fljótlega eftir greiningu en hinir lifðu af án nýrrar aðgerðar. Fengu peir sýklalyfjameðferð í æð samkvæmt ræktunum og næmiprófi.

Á mynd 2 sést heildarlifun fyrir alla sjúklingana 156 og var eins árs lifun $89,7 \%$ og fimm ára lifun $78,2 \%$. Á myndinni sést einnig samanburður á heildarlifun sjúklinganna og áætlaðrar lifunar sambærilegs hóps Íslendinga miðað við aldur, kyn og rannsóknartímabil. Fyrsta mánuðinn var dánarhlutfall hærra í aðgerðarhópnum, en eftir 48 mánuði skarast kúrfurnar og eftir pað er ekki marktækur munur á lifun hópanna. Mynd 3 sýnir sjúkdómssértæka lifun sem var 93,5\% ári frá aðgerð og 90,7\% eftir fimm ár.

\section{Umræða}

Niðurstöður rannsóknarinnar benda til pess að langtímaárangur pessara aðgerða sé sambærilegur og lýst hefur verið í öðrum rannsóknum. ${ }^{10}$ Rúmur fjórðungur (26,3\%) sjúklinga lagðist inn vegna lokutengdra vandamála og heildartíðni langtímafylgikvilla reyndist 6/100 sjúklingaár. Af langtímafylgikvillum voru blæðingar og blóðsegarek algengust en tíðni hjartapelsbólgu reyndist lægri. Samanburður á tíðni langtímafylgikvilla fyrir gervilokur og lífrænar lokur í nokkrum helstu rannsóknum er sýndur í töflu II.

Engin tilfelli af segamyndun á hjartaloku greindust og ekki purfti að skipta út neinum hjartalokum vegna skemmda eða bilana (SVD). Рó parf að hafa hugfast að meðaleftirlitstími í pessari rannsókn var aðeins 4,8 ár en lífrænar hjartalokur endast að jafnaði mun lengur. ${ }^{5}$ Eftir 10 ár er tíðni bilaðra lífrænna loka 2-5\% í erlendum rannsóknum og vex svo ár frá ári (10-25\% eftir

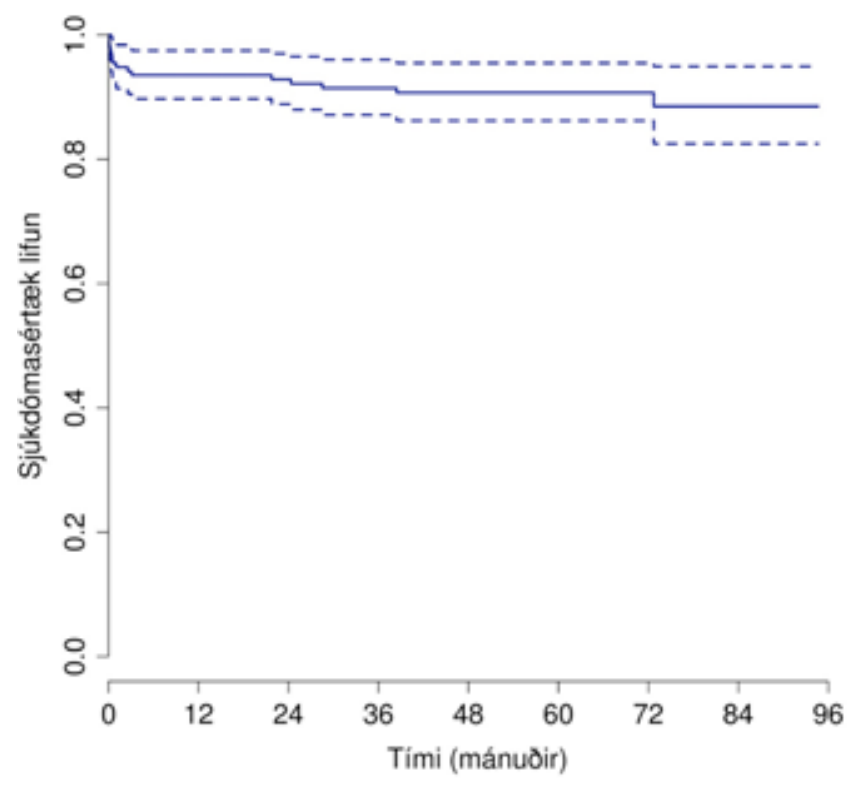

Mynd 3. Sjúkdómasértæk lifun sjúklinga sem gengust undir lokuskipti vegna ósæðarlokuprengsla á Íslandi á tímabilinu 2002-2006. Brotalínur sýna 95\% vikmörk.

15 ár og 30-45\% eftir 20 ár). ${ }^{11,12}$ Pví svarar pessi rannsókn ekki spurningunni um endingu lífrænna loka, né heldur hvort lífrænar lokur með grind endist betur en grindarlausar lokur. Par sem meðalaldur sjúklinga sem fengu lífræna loku var hár (75 ár) má gera ráð fyrir að endingartími lokanna sé í mörgum tilvikum betri en áætlaðar lífslíkur. Til eru rannsóknir á sjúklingum sem fengu svínalokur með grind par sem eftirfylgdartími var rúmlega tveir áratugir. ${ }^{11}$ Tíðni lokubilana reyndist 30\% eftir 20 ár og 7\% sjúklinga purftu enduraðgerð vegna lokutengdra vandamála. Færri rannsóknir eru til fyrir grindarlausar lífrænar lokur enda hafa pær verið skemur á markaði og aðeins í nokkrum peirra hefur sjúklingum verið fylgt eftir lengur en í áratug. ${ }^{13-16}$

Tafla II. Samanburður á rannsóknum á tíðni langtímafylgikvilla eftir ósæðarlokuskipti. Fylgikvillar eru gefnir upp miðað við 100 sjúklingaár.

\begin{tabular}{|c|c|c|c|c|c|c|}
\hline $\begin{array}{l}\text { Rannsókn } \\
\text { (ár) }\end{array}$ & $\begin{array}{l}\text { Loku- } \\
\text { gerð }\end{array}$ & $\begin{array}{l}\text { Sjúk- } \\
\text { lingaár }\end{array}$ & $\begin{array}{l}\text { Blæd- } \\
\text { ingar }\end{array}$ & $\begin{array}{l}\text { Blóð- } \\
\text { segarek }\end{array}$ & $\begin{array}{c}\text { Hjartapels- } \\
\text { bólga }\end{array}$ & $\begin{array}{l}\text { Sega- } \\
\text { myndun } \\
\text { á loku }\end{array}$ \\
\hline $\begin{array}{l}\text { Emery } \\
(2005)^{7}\end{array}$ & $\begin{array}{l}\text { St. Jude } \\
\text { Medical }^{\circledR} \\
\text { gerviloka }\end{array}$ & 21.741 & 2,7 & 1,9 & 0,2 & 0,06 \\
\hline Khan $(2001)^{5}$ & $\begin{array}{l}\text { St. Jude } \\
\text { Medical }^{\circledR} \\
\text { gerviloka }\end{array}$ & 3881 & 2,0 & 2,5 & 0,3 & 0,3 \\
\hline $\begin{array}{l}\text { Butchart } \\
(2001)^{22}\end{array}$ & $\begin{array}{c}\text { Medtronic } \\
\text { Hall } \\
\text { gerviloka }\end{array}$ & 5120 & 1,2 & 2,3 & 0,4 & 0,04 \\
\hline Khan $(2001)^{5}$ & $\begin{array}{l}\text { Lifrænar } \\
\text { lokur }\end{array}$ & 3387 & 0,7 & 2,1 & 0,6 & 0,0 \\
\hline $\begin{array}{l}\text { Bach } \\
(2005)^{23}\end{array}$ & $\begin{array}{l}\text { Medtronic } \\
\text { Freestyle }\end{array}$ & 4488 & 0,8 & 2,7 & 0,4 & 0,05 \\
\hline $\begin{array}{l}\text { Eichinger } \\
(2008)^{11}\end{array}$ & $\begin{array}{l}\text { St. Jude } \\
\text { Medical } \\
\text { Biocor }^{\sqrt{10}}\end{array}$ & 3321 & 0,8 & 2,1 & 0,5 & $\begin{array}{l}\text { Ekki tekió } \\
\text { fram }\end{array}$ \\
\hline $\begin{array}{l}\text { Viktorsson } \\
\text { (2010) }\end{array}$ & $\begin{array}{c}\text { Ýmsar } \\
\text { lokugerðir }\end{array}$ & 749 & 1,6 & 1,6 & 0,7 & 0,0 \\
\hline
\end{tabular}


Til að komast hjá ævilangri blóðpynningu á eldri einstaklingum eru oftast settar lífrænar lokur í sjúklinga sem komnir eru yfir 65 ára aldur. ${ }^{17}$ Svo var einnig í pessari rannsókn, með einstaka undantekningum pó. Nokkrir eldri sjúklingar sem fengu gerviloku voru pegar á ævilangri blóðpynningarmeðferð af öðrum orsökum, til dæmis vegna gáttatifs eða sögu um lungnablóðrek. Einnig getur komið til greina að nota lífræna loku hjá yngri konum sem ekki vilja taka warfarín á meðgöngu par sem lyfið getur valdið fósturskemmdum. Ending lífrænu lokanna er pó síðri í yngri sjúklingum og pessir einstaklingar geta purft nýja aðgerð síðar á ævinni. Skurðdauði er pá tvöfalt hærri en við fyrstu opnu lokuskiptin. ${ }^{6}$

Blæðingatengd vandamál og blóðsegarek frá lokunum eru algengustu langtímafylgikvillarnir og eru jafnframt á meðal peirra hættulegustu. ${ }^{7}$ Tíðni beggja fylgikvilla er umtalsvert hærri hjá sjúklingum með gerviloku en blæðingar tengjast pá ævilangri blóðpynnandi meðferð. ${ }^{18}$ Oft eru pessi vandamál í öfugu hlutfalli, pannig að eftir pví sem blæðingavandamál eru algengari er tíðni blóðsegareks lægri. ${ }^{19}$ Eftirlit með blóðpynningu er pví mikilvægt og pá sérstaklega nákvæmt eftirlit með INR-mælingum.

Par sem tíðni alvarlegra blæðinga er tiltölulega lág hér á landi má leiða líkur að pví að fyrirkomulag eftirlits með blóðpynningarmeðferð sé í góðum farvegi. Oftast purfa sjúklingar að koma í mælingu á nokkurra vikna fresti. Sjúklingi er síðan tilkynnt niðurstaðan símleiðis og um leið gerð breyting á warfarínskammti ef við á. Erlendis er hins vegar sums staðar farið að notast við mælingar sem sjúklingar geta framkvæmt sjálfir heima hjá sér. ${ }^{20}$

Tíðni hjartapelsbólgu reyndist sambærileg við aðrar rannsóknir par sem hún er yfirleitt svipuð fyrir lífrænar lokur og gervilokur. ${ }^{5}$ Tíðni segamyndunar var mjög lág, sem skýrist sennilega af háu hlutfalli lífrænna loka í pessari rannsókn.

Tíðni hjartadreps var 0,3/100 sjúklingaár og hjartabilunar 1,7/100 sjúklingaár. Skráning og mat á orsökum hjartadreps og hjartabilunar er flókin, meðal annars vegna kransæðasjúkdóms sem margir pessara sjúklinga eru með samhliða ósæðarlokuprengslum. Pví er erfitt að bera niðurstöður okkar saman við aðrar rannsóknir.

Heildarlifun sjúklinganna ári eftir aðgerð reyndist vera 89,2\% og 78,2\% eftir fimm ár. Sjúkdómasértækar lífshorfur eftir eitt og fimm ár mældust 93,5\% og 90,7\%. Petta er sambærileg lifun og í erlendum rannsóknum. ${ }^{5}$ Pegar leið á eftirfylgdartímann skárust lifunarkúrfa sjúklingapýðisins og áætluð lifunarkúrfa sambærilegs hóps Íslendinga. Рað bendir til pess að dánartíðni pýðisins sé ekki frábrugðin dánartíðni Íslendinga pegar líður frá lokuskiptum. Petta er staðreynd prátt fyrir aukna og viðbúna dánartíðni skömmu eftir aðgerðina (skurðdauði). Svipuðum niðurstöðum hefur verið lýst í sænskri rannsókn á öldruðum sem fengu lífræna loku með grind. ${ }^{21}$

Styrkleiki pessarar rannsóknar er að hún tekur til allra sjúklinga sem gengust undir ósæðarlokuskipti hjá heilli pjóð á fimm ára tímabili. Aðeins prír skurðlæknar framkvæmdu aðgerðirnar og nákvæmar upplýsingar fundust um afdrif allra sjúklinganna nema sjö. Einnig telst styrkur að sjúklingar voru fundnir með leit í tveimur aðskildum skrám, sem minnkar líkur á pví að einhverjir sjúklingar hafi ekki verið teknir með í rannsóknina.

Fyrir utan að pessi rannsókn er afturskyggn og óslembuð er veikleiki hversu ófullkomnar upplýsingar um ómskoðun við eftirfylgd reyndust. Pannig vantaði upplýsingar hjá 50 sjúklingum en 34 peirra höfðu að öllum líkindum aldrei farið í ómskoðun á hjarta eftir að peir útskrifuðust af sjúkrahúsi. Hjá hinum 16 fundust ómsvör ekki prátt fyrir ítarlega leit. Einnig vantaði upplýsingar um meðalprýstingsfall hjá 79\% sjúklinga, bæði fyrir og eftir aðgerð, og pví var einungis hægt að gefa upp hámarksprýstingsfall.

Í heildina eru langtímafylgikvillar eftir ósæðarlokuskipti á Íslandi svipaðir og í öðrum rannsóknum, en eftirlitstími er frekar stuttur. Áberandi er að blæðingar sem tengdust blóðpynnandi meðferð eru fátíðari, en tíðni blóðsegareks og hjartapelsbólgu svipuð og erlendis. Sjúkdómasértæk langtímalifun sjúklinganna var góð og fimm ára lifun sambærileg við lifun Íslendinga af sama aldri og kyni sem ekki höfðu farið í aðgerð. Langtímaárangur pessara aðgerða telst pví góður, ekki síst pegar haft er í huga hversu alvarlegur lokusjúkdómurinn var fyrir aðgerð.

\section{Pakkir}

Pakkir fær Gunnhildur Jóhannsdóttir skrifstofustjóri á skurðdeild Landspítala og læknaritarar í Læknasetri fyrir aðstoð við öflun sjúkragagna. Auk peirra fá hjartalæknar á Landspítala, Sjúkrahúsinu á Akureyri, Læknasetrinu og Hjartamiðstöðinni pakkir fyrir veittar upplýsingar og aðgang að sjúklingagögnum. Loks fær Thor Aspelund tölfræðingur Hjartaverndar og dósent við Háskóla Íslands pakkir fyrir aðstoð við lifunarútreikninga. 


\section{Heimildir}

1. Arnórsson T, Torfason B, Ólafsson G, Alfreðsson $\mathrm{H}_{,}$ Jóhannsson KB, Guðbjartsson T. Hjartaskurðlækningar á Íslandi í 20 ár. Ágrip erinda af vísindapingi Skurolæknafélags Íslands og Svæfinga- og giörgæslulæknafélags Íslands. E 24. Læknablaðið 2007; 93: 320.

2. Rajamannan NM, Bonow RO, Rahimtoola SH. Calcific aortic stenosis: an update. Nat Clin Pract Cardiovasc Med 2007; 4: 254-62.

3. Pai RG, Kapoor N, Bansal RC, Varadarajan P. Malignant natural history of asymptomatic severe aortic stenosis: benefit of aortic valve replacement. Ann Thorac Surg 2006; 82: 2116-22.

4. Krane M, Voss B, Hiebinger A, et al. Twenty years of cardiac surgery in patients aged 80 years and older: risks and benefits. Ann Thorac Surg 2011; 91: 506-13 .

5. Khan SS, Trento A, DeRobertis M, et al. Twenty-year comparison of tissue and mechanical valve replacement. Thorac Cardiovasc Surg 2001; 122: 257-69.

6. Toole JM, Stroud MR, Kratz JM, et al. Twenty-five yea experience with the St. Jude medical mechanical valve prosthesis. Ann Thorac Surg 2010; 89: 1402-9.

7. Emery RW, Krogh CC, Arom KV, et al. The St. Jude Medical cardiac valve prosthesis: a 25-year experience with single valve replacement. Ann Thorac Surg 2005; 79: 776-82; discussion 82-3.

8. Ingvarsdóttir IL, Viktorsson SA, Helgadóttir $\mathrm{S}$, et al Lokuskipti vegna ósæðarlokubrengsla á Íslandi 2002-2006: Ábendingar og snemmkomnir fylgikvillar. Læknablaðið 2011; 97: 523-7.

9. Akins CW, Miller DC, Turina MI, et al. Guidelines for reporting mortality and morbidity after cardiac valve interventions. J Thorac Cardiovasc Surg 2008; 135: 732-8.
10. Doty JR, Flores JH, Millar RC, Doty DB. Aortic valve replacement with medtronic freestyle bioprosthesis: operative technique and results. J Card Surg 1998; 13: 208 17.

11. Eichinger WB, Hettich IM, Ruzicka DJ, et al. Twenty-yea experience with the St. Jude medical Biocor bioprosthesis in the aortic position. Ann Thorac Surg 2008; 86: 1204-10.

12. David TE, Ivanov J, Armstrong $S$, Feindel CM, Cohen $\mathrm{G}$. Late results of heart valve replacement with the Hancock II bioprosthesis. J Thorac Cardiovasc Surg 2001; 121: 268-77.

13. Vrandecic M, Fantini FA, Filho BG, de O, da C, Vrandecic E. Long-term results with the Biocor-SJM stentless porcine aortic bioprosthesis. J Heart Valve Dis 2002; 11: 47-53.

14. Polvani G, Barili F, Dainese L, et al. Long-term results after aortic valve replacement with the Bravo 400 stentless xenograft. Ann Thorac Surg 2005; 80: 495-501.

15. Ali A, Lim E, Halstead J, et al. Porcine or human stentless valves for aortic valve replacement? Results of a 10-year comparative study. J Heart Valve Dis 2003; 12: 430-5 discussion 435

16. Auriemma S, D'Onofrio A, Brunelli M, et al. Long-term results of aortic valve replacement with Edwards Prim Plus stentless bioprosthesis: eleven years' follow up. Heart Valve Dis 2006; 15:6 91-5; discussion 695

17. Bonow RO, Carabello BA, Chatterjee K, et al. 2008 focused update incorporated into the ACC/AHA 2006 guidelines for the management of patients with valvular heart disease: a report of the American College of Cardiology/American Heart Association Task Force on Practice Guidelines (Writing Committee to revise the 1998 guidelines for the management of patients with valvular heart disease). Endorsed by the Society of Cardiovascular Anesthesiologists, Society for Cardiovascular Angiography and Interventions, and Society of Thoracic Surgeons. J Am Coll Cardiol 2008; 52: e1-142.
18. Cannegieter SC, Rosendaal FR, Briet E. Thromboembolic and bleeding complications in patients with mechanical heart valve prostheses. Circulation 1994; 89: 635-41.

19. Horstkotte D, Schulte H, Bircks W, Strauer B. Unexpected findings concerning thromboembolic complications and anticoagulation after complete 10 year follow up of patients with St. Jude Medical prostheses. J Heart Valve Dis 1993; 2: 291-301.

20. Koertke $H$, Minami $K$, Boethig $D$, et al. INR selfmanagement permits lower anticoagulation levels after mechanical heart valve replacement. Circulation 2003; 108 Suppl 1: II75-8.

21. Sjogren J, Gudbjartsson T, Thulin LI. Long-term outcome of the MitroFlow pericardial bioprosthesis in the elderly after aortic valve replacement. J Heart Valve Dis 2006; 15: 197-202.

22. Butchart EG, Li HH, Payne N, Buchan K, Grunkemeier GL Twenty years' experience with the Medtronic Hall valve. J Thorac Cardiovasc Surg 2001; 121: 1090-100

23. Bach DS, Kon ND, Dumesnil JG, Sintek CF, Doty DB. Ten-year outcome after aortic valve replacement with the freestyle stentless bioprosthesis. Ann Thorac Surg 2005; 80: 480-6; discussion 486-7.

ENGLISH SUMMARY

\section{Aortic valve replacement for aortic stenosis in Iceland 2002-2006: Long term complications and survival}

Viktorsson SA, Ingvarsdottir IL, Hreinsson K, Sigurdsson MI, Helgadottir S, Arnorsson Th, Danielsen R, Gudbjartsson T

Objective: To investigate long-term complications and survival following aortic valve replacement (AVR) in patients with aortic stenosis (AS) in Iceland. Material and methods: Included were 156 patients (average age $71.7 \mathrm{yrs}, 64.7 \%$ males) that underwent AVR for AS at Landspitali between 2002 and 2006. A mechanical prosthesis was used in 29 patients (18.6\%) and a bioprosthesis in 127. Long-term complications and operation-related admissions were registered from hospital and outpatient records until April 1, 2010. Overall survival was estimated and compared with the Icelandic population of the same age and gender.

Results: The mean preop. EuroSCORE(st) was $6.9 \%$, the max. transvalvular pressure gradient $74.1 \mathrm{mmHg}$ and the left ventricular ejection fraction (LVEF) (57.2\%). At six months following AVR the maximal pressure gradient was $19.8 \mathrm{mmHg}$ (range; 2.5 -38). Echocardiography results were not available for $23.6 \%$ of the patients 6 months postoperatively. In the follow-up period one in four patients was admitted due to valve-related problems. Re-admission rate was 6.0/100 patient-years (pt-y); most commonly due to cardiac failure (1.7/100 pt-y), emboli (1.6/100 pt-y), hemorrhage (1.6/100 pt-y), endocarditis $(0.7 / 100 \mathrm{pt}-\mathrm{y})$ and myocardial infarction $(0.4 / 100 \mathrm{pt}-\mathrm{y})$. Survival at 1 and 5 year was $89.7 \%$ and $78.2 \%$, respectively, making survival comparable to the estimated survival of Icelanders of the same age and gender.

Conclusions: The rate of long-term complications following AVR in Iceland is in line with other studies. The same applies to long-term survival, which was similar to that of the Icelandic population of the same age and gender.

Key words: Aortic valve replacement, aortic stenosis, heart surgery, results, long-term complication, survival.

Correspondence: Tómas Guðbjartsson, tomasgud@landspitali.is 